\title{
Multi-scale feedbacks between tree regeneration traits and herbivore behavior explain the structure of pasture- woodland mosaics
}

\author{
Alexander Peringer $\cdot$ Kiowa A. Schulze - Ileana Stupariu • \\ Mihai-Sorin Stupariu • Gert Rosenthal • Alexandre Buttler • \\ François Gillet
}

Received: 28 October 2014/ Accepted: 7 November 2015/Published online: 24 November 2015

(C) Springer Science+Business Media Dordrecht 2015

\begin{abstract}
Context The pasture-woodlands of Central Europe are low-intensity grazing systems in which the structural richness of dynamic forest-grassland mosaics is causal for their high biodiversity. Distinct mosaic patterns in Picea abies- and Fagus sylvatica-dominated pasture-woodlands in the Swiss Jura Mountains suggest a strong influence of tree species regeneration ecology on landscape structural properties. At the landscape scale, however, cause-effect relationships are complicated by habitat selectivity of livestock.

Objectives We asked which tree species regeneration traits and what kind of feedbacks among local-
\end{abstract}

Electronic supplementary material The online version of this article (doi:10.1007/s10980-015-0308-z) contains supplementary material, which is available to authorized users.

A. Peringer $(\bowtie) \cdot$ A. Buttler $\cdot$ F. Gillet

Ecole Polytechnique Fédérale de Lausanne EPFL, School of Architecture, Civil and Environmental Engineering

ENAC, Laboratory of Ecological Systems ECOS, Station

2, Lausanne 1015, Switzerland

e-mail: ap@ilpoe.uni-stuttgart.de

A. Peringer $\cdot$ A. Buttler

WSL Swiss Federal Institute for Forest, Snow and Landscape Research, Site Lausanne, Station 2,

Lausanne 1015, Switzerland

\section{K. A. Schulze - G. Rosenthal}

Institute of Landscape and Vegetation Ecology,

University of Kassel, Gottschalkstr. 26a, 34127 Kassel,

Germany scale vegetation dynamics and landscape-scale herbivore behavior are causal for the contrasted landscape structural characteristics of Picea- and Fagus-dominated pasture-woodlands.

Methods We performed simulation experiments of mosaic pattern formation in both pasture-woodland types. The regeneration traits, namely dispersal distance, resistance to browsing and tolerance to shade, and the rules for habitat selection of cattle were modified and the corresponding shifts in landscape structure were analyzed.

Results Dispersal distance showed a significant, but only local, effect promoting forest fringe formation. Saplings' resistance to browsing mainly determined overall tree cover, but did not influence landscape structure. At the landscape scale, both shade tolerance of saplings and selective habitat use by cattle were

\author{
I. Stupariu · M.-S. Stupariu \\ Institute of Research of University of Bucharest (ICUB), \\ Splaiul Independentei nr. 91-95, 050095 Bucharest, \\ Romania \\ I. Stupariu · M.-S. Stupariu \\ Transdisciplinary Research Centre Landscape-Territory- \\ Information Systems (CeLTIS), Splaiul Independentei nr. \\ 91-95, 050095 Bucharest, Romania \\ I. Stupariu \\ Department of Regional Geography and Environment, \\ Faculty of Geography, University of Bucharest, Bd. \\ N. Balcescu, 010041 Bucharest, Romania
}


responsible for forest-grassland segregation: high shade tolerance triggered segregation, whereas nonselective habitat use hindered it.

Conclusions Existing local-scale theory on pasturewoodland dynamics is complemented by an herbivorevegetation feedback among spatial scales. In lowintensity pastures, where large herbivores are preferentially "grazers" and trees form dense canopies, an intrinsic trend towards forest-grassland segregation at the expense of forest-grassland ecotones is predicted.

Keywords Forest-grassland segregation ·

Herbivore-vegetation interaction · Rewilding .

Norway spruce Picea abies - European beech Fagus sylvatica $\cdot$ Swiss Jura Mountains

\section{Introduction}

Pasture-woodland landscapes are mosaic ecosystems that have been developed to provide multiple ecosystem services under harsh environmental conditions in Central European mountainous regions. The traditional management combined livestock breeding and wood production among other benefits. Today, these semi-open landscapes are hotspots of biodiversity and represent an important European cultural heritage for inherently linking landscape beauty to land-use traditions (Hartel and Plieninger 2014). During the past century, pasture-woodlands declined all over Europe. The biodiversity of remnant systems suffered from the simplification of mosaic patterns, for which both the intensification of land-use and abandonment have been identified as major causes (Etienne 1996; Perrenoud et al. 2003; Bergmeier et al. 2010; Chételat et al. 2013).

The semi-open landscape structure of low-intensity pasture-woodlands depends on a balance between the (progressive) successional trend towards forest

\footnotetext{
$\overline{\text { M.-S. Stupariu }}$

Faculty of Mathematics and Computer Science, University of Bucharest, Academiei Str. 14, 010041 Bucharest, Romania

F. Gillet

Université de Bourgogne Franche-Comté, UMR CNRS

6249 Chrono-Environnement, 16 route de Gray,

25030 Besançon Cedex, France
}

development and the (regressive) impact of large herbivores on tree establishment and growth (Gillet and Gallandat 1996; Lederbogen et al. 2004; Hartel and Plieninger 2014). Moreover, pastures were cleared by logging and cutting of unpalatable or thorny shrubs. In the oak- (Quercus spp.) dominated parks in England (e.g. Hopkins and Kirby 2007; Jørgensen 2013) and Romania (Hartel et al. 2013) for example, such anthropogenic interference was high and governed landscape structure to a large extent. In low-intensity grazing systems, however, the natural processes of progressive and regressive successions essentially contribute to mosaic pattern formation (Rosenthal 2010).

Increasing agro-economic pressure generally led to a simplification of traditional multiple land uses with a current focus on livestock breeding and the cessation of shrub clearing or logging due to the low wood productivity in harsh mountain climate and the difficult accessibility of steep terrain. Low-intensity grazing is increasingly preferred as a tool for the longterm management of semi-open landscapes (e.g. Redecker et al. 2002; Rosenthal et al. 2012) and wild ungulates form an intrinsic part in upcoming applications of the "rewilding" paradigm in nature conservation (Donlan et al. 2006; Navarro and Pereira 2012). In all cases, herbivore-vegetation interactions are more important for the future development of semiopen landscape mosaics than direct human interference. As habitat richness, biodiversity and many threatened species depend on the landscape mosaic structure, the causal understanding of the underlying mechanisms and feedbacks in pattern formation is of great importance for nature conservation purposes. Furthermore, climate-change adapted management requires the understanding of the role of tree species ecology in mosaic pattern formation. The climatechange driven upward shift of vegetation zones in the mountains projects the immigration of new tree species into pasture-woodlands (e.g. Iverson and McKenzie 2013). Consequently, mosaic patterns might shift according to their distinct behavior in progressive and regressive successions.

In our study, we investigated the role of tree species regeneration traits and related herbivore-vegetation interactions using two contrasted pasture-woodland types as model ecosystems that are located at the crest of the High Range of the Swiss Jura Mountains. Here, pasture-woodlands show distinct landscape patterns 
Fig. 1 Landscape structure in extensively managed high-altitude pasturewoodlands of the Swiss Jura Mountains when dominated by spruce or by beech. Aerial photographs were classified into phytocoenosis types defined by tree cover (Table 1) in grids of $25 \mathrm{~m}$ square cell width

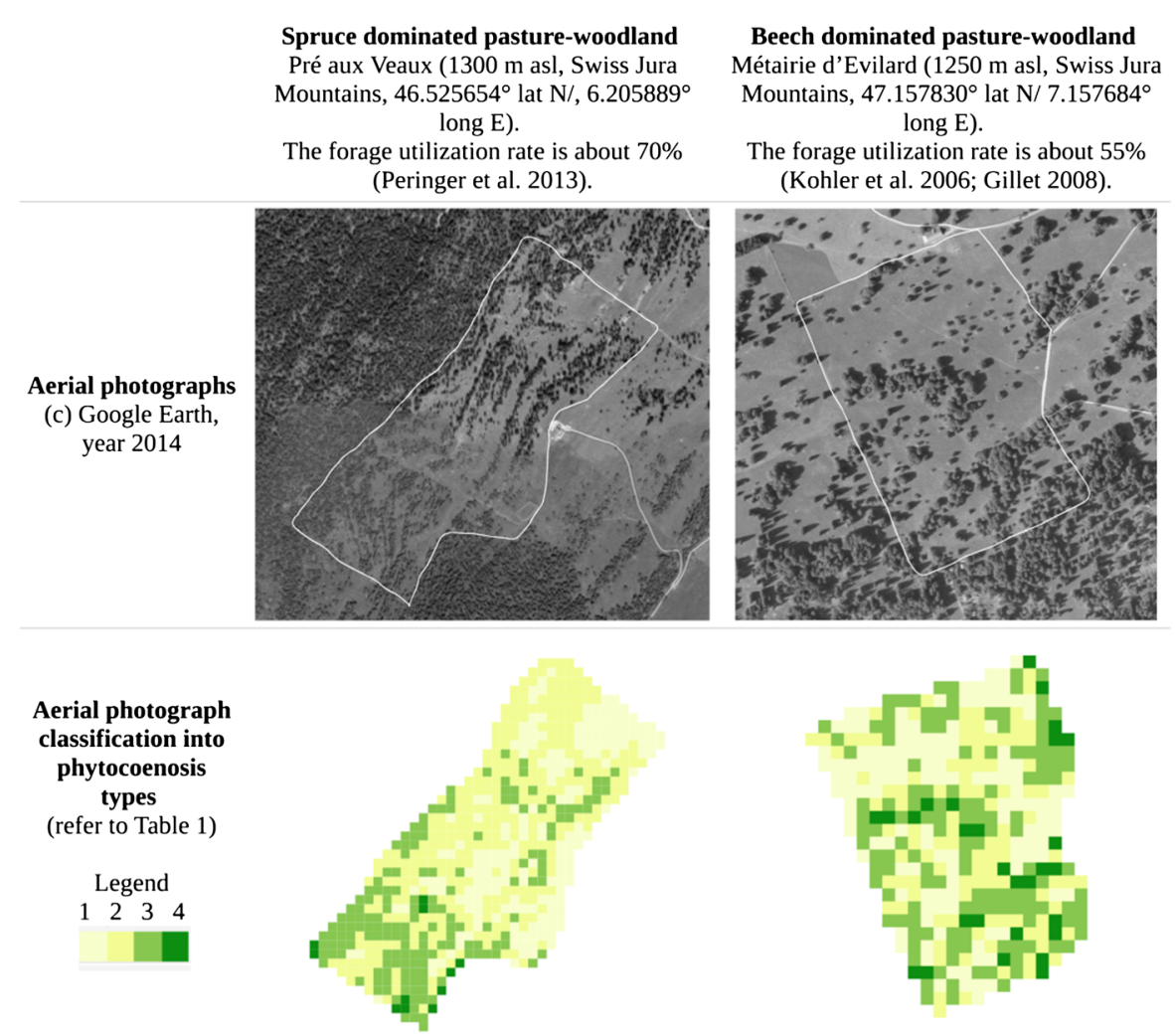

Table 1 Structural definition of phytocoenosis types (Gallandat et al. 1995)

\begin{tabular}{|c|c|}
\hline Code & Definition of phytocoenosis type \\
\hline 1 & Unwooded pasture with tree cover below $1 \%$ \\
\hline 2 & $\begin{array}{l}\text { Sparsely wooded pasture with tree cover ranging } \\
\text { between } 1 \text { and } 20 \% \text {, trees or bushes being mostly } \\
\text { scattered }\end{array}$ \\
\hline 3 & $\begin{array}{l}\text { Densely wooded pasture with tree cover ranging } \\
\text { between } 20 \text { and } 70 \% \text {, with trees clustered in thickets }\end{array}$ \\
\hline 4 & $\begin{array}{l}\text { Grazed forest with tree cover higher than } 70 \% \text {, } \\
\text { appearing as forest with a closed canopy }\end{array}$ \\
\hline
\end{tabular}

when dominated by Norway spruce (Picea abies) or by European beech (Fagus sylvatica), although grazed by the same type of livestock, i.e. cattle (refer to Pré aux Veaux and Métairie d'Evilard in Fig. 1). The classification of aerial photographs regarding tree cover and corresponding phytocoenosis types (Table 1) quantifies their structural characteristics (Fig. 2). Spruce forms a coarse-grained distribution of phytocoenosis types with a dominance of gradual transitions from forest to grassland (sparsely wooded pastures, type 2 , covering $47 \%$ of the landscape).
These large ecotone areas form large and aggregated patches (high type specific cover, Aggregation Index AI and Total Core Area TCA in the diagram in Fig. 2). To the contrary, beech forms a fine-grained pattern of sharply delineated woodland and grassland patches. Forest and grasslands are segregated, as ecotones are narrow fringes around the woods. Forest-grassland ecotones are low in cover (phytocoenosis type 2 covering $26 \%$ of the landscape), and the landscape is dominated by either grassland or densely wooded pasture (67\% in sum). The spatial distribution of ecotones is highly disaggregated and fine grained (low type specific AI and TCA in the diagram in Fig. 2). In sum, the landscape metrics for phytocoenosis types ranging from grassland to forest (x-axis in the diagrams of Fig. 2) show contrasted characteristics for the spruce- and the beech-dominated landscape. In the beech-dominated landscape, the cover, the TCA and the AI are minimal for ecotones when compared to grassland or densely wooded pasture (diagram in Fig. 2). To the contrary, in the spruce-dominated landscape these indices do not show minimal values, but peak for ecotones (diagram in Fig. 2). In the beech-dominated landscape, the type specific cover, 


\begin{tabular}{|c|c|c|}
\hline Study area & $\begin{array}{l}\text { Spruce-dominated Pré } \\
\text { aux Veaux }\end{array}$ & $\begin{array}{c}\text { Beech-dominated Métairie } \\
\text { d'Evilard }\end{array}$ \\
\hline $\begin{array}{c}\text { Landscape metrics } \\
\text { for entire landscape } \\
\text { PD / ED } \\
\text { TCA / CONTAG / AI }\end{array}$ & $\begin{array}{c}55 / 137 \\
6.44 / 26 / 59\end{array}$ & $\begin{array}{c}184 / 274 \\
0.94 / 11 / 44\end{array}$ \\
\hline $\begin{array}{l}\text { Envelope-patterns along the } \\
\text { gradient from grassland to forest } \\
\text { Cover of phytocoenosis types } \\
\text { (black), } \\
\text { AI (grey, both left y-axis), } \\
\text { TCA (grey, dashed, right y-axis) }\end{array}$ & Phytocoenosis types & $\begin{array}{ccc}100 \\
\text { Phytocoenosis types }\end{array}$ \\
\hline
\end{tabular}

Fig. 2 Structural analysis of observed landscapes depicted in Fig. 1. The spruce-dominated Pré aux Veaux is a coarse grained landscape with few but large patches of phytocoenosis types (low patch density PD and large total core area TCA), which are aggregated (high contagion index CONTAG and aggregation index AI). To the contrary, the beech-dominated Métairie d'Evilard is a highly heterogeneous landscape with a fine-

the TCA and the AI collectively show an "envelope distribution" along the gradient from grassland to forest that denotes the characteristic landscape pattern of forest-grassland segregation. In the spruce-dominated landscape, the type specific cover, the TCA and the AI collectively show an "inverted envelope distribution" along the gradient from grassland to forest that denotes a highly contiguous landscape. We refer to this collective interpretation of landscape metrics as "landscape structural envelope".

Tree species regeneration traits, namely seed dispersal distances, saplings' resistance to browsing and shade tolerance are the most important traits determining encroachment and stand regeneration processes in mosaic landscapes (Peringer 2008; Vandenberghe et al. 2008). Seed dispersal is considered a determinant process for the spatial extent of tree colonization pattern and the "width" of forest fringes (Peringer and Rosenthal 2011). Spruce seeds disperse widespread in large amount by anemochory and seed densities gradually decline with distance to mother trees (e.g. Dovčiak et al. 2008). For beech seeds, barochorous and zoochorous dispersal by birds and small mammals are important (Jensen 1985; Johnson and Adkisson 1985). The combination of these two dispersal vectors leads to a concentration of seeds in the close neighborhood of mother trees (Martínez and González-Taboada 2009) and to a scattered seed shadow in longer distance (Kunstler et al. 2004). grained distribution of phytocoenosis types (high PD and edge density ED, small TCA), which are disaggregated (low CONTAG and AI). For the description of the envelope-patterns refer to the text. For the definition of phytocoenosis types refer to Table 1, for the definition of landscape metrics refer to "Landscape analysis"

Browsing on tree saplings controls tree colonization in pasture-woodlands (Vandenberghe 2006; Smit et al. 2015). Spruce saplings resist browsing well and colonization can be observed also far away from mother trees, where seed densities are low (Dovčiak et al. 2008). In contrast, beech saplings poorly resist browsing and, as a consequence, survival rates are low. Only few scattered trees might establish even from high seed numbers in seed deposits created by birds and small mammals outside the beech stands. Under high grazing pressure, establishment patterns of beech might be further constrained to the distribution of nurse shrubs (Olff et al. 1999; Smit et al. 2007). The tree sapling's tolerance to shade determines the regeneration success under the canopy of mother trees and therefore the stand density. Beech saplings are highly shade tolerant and in turn beech stands develop dense canopies. The light demand of spruce seedlings is high under harsh habitat conditions (Ammer 1998), which explains the thin canopies at the Swiss Jura crest (Fig. 1).

In a first glance résumé, these local-scale effects of tree species regeneration traits on forest fringe and canopy formation can explain the observed landscape structures. Viewed along the pathway of progressive succession, spruce forms large forest-grassland ecotones due to good colonization performance (widespread dispersal and high browsing resistance). Beech mainly forms narrow forest fringes due to restricted 
dispersal and scattered isolated trees from longdistance dispersal in combination with facilitation by nurse shrubs. The intimate coupling of these progressive processes of woodland formation with regressive succession driven by herbivore-vegetation interactions is then however disregarded (Wallis De Vries and Schippers 1994). The behavior of large herbivores is determined by landscape patterns (forage availability and tree cover distribution). Subsequently their grazing and browsing impacts are heterogeneously distributed in forest-grassland mosaics. Cattle prefer treeless grasslands with high forage availability and quality ("grazer" sensu Hofmann and Scheibe 1997), whereas forests and shrublands are disregarded (Kohler et al. 2006). Cattle browse on seedlings and saplings during their main foraging activity. Browsing is thereby focused on the main forage areas, i.e. grasslands. Altogether, a feedback emerges. Woody plant encroachment and forest canopy closure determine cattle behavior at the landscape scale and the allocation of browsing pressure, which in turn controls local-scale encroachment and stand regeneration in the long run. We hypothesize that this multi-scale feedback mechanism among trait-conditioned localscale vegetation dynamics and landscape-scale selective habitat use of large herbivores essentially contributes to mosaic pattern formation in pasturewoodlands. The feedback is potentially critical for the response of mountain pasture-woodlands to climate change and the projection of landscape dynamics in wilderness areas. Prolonged growing seasons and increased nutrient availability (Rustad et al. 2001) reduce the tree saplings minimal demand for light and enhance their growth ability after browsing. Even slightly accelerated encroachment dynamics and forest canopy densification might lead to shifts in landscape structure, when amplified by the feedback with herbivore behavior. Wilderness areas might develop mosaic patterns that largely differ from what is expected based on pasture-woodland research due to the distinct habitat preferences of wild ungulates and livestock. In turn, their value for nature conservation is hard to predict.

Much work has been done on the effects of lowintensity grazing on vegetation dynamics in pasturewoodlands (e.g. Wallis De Vries et al. 1998). Causeeffect relationships, however, have been demonstrated mainly at the local scale and for the short- and the midterm due to the limited time span of experimental studies and of space-for-time substitution approaches (e.g. Smit et al. 2015). Therefore, the potential multiscale feedbacks in herbivore-vegetation interactions during the long-term formation of pasture-woodland mosaic landscapes have not been investigated yet. We performed a modeling study to examine the role of tree species regeneration traits in the formation of segregated (beech-like) and contiguous (spruce-like) pasture-woodland mosaics under explicit consideration of feedbacks in herbivore-vegetation interactions between spatial scales. We asked specifically:

(i) Which local-scale (structure and width of forest-grassland ecotones, tree canopy densities) and landscape-scale characteristics (overall tree cover, contiguous vs. segregated structure) of pasture-woodlands emerge from the specific regeneration traits of spruce and beech under cattle grazing?

(ii) Do landscape-scale characteristics, specifically a contiguous versus a segregated structure, depend on the habitat selectivity of cattle and thereby on a multi-scale feedback in herbivore-vegetation interactions?

\section{Methods}

We applied the spatially explicit simulation model of wood-pasture ecosystem dynamics WoodPaM (Gillet 2008; Peringer et al. 2013) to artificial landscapes that represented spruce and beech-dominated pasturewoodland ecosystems in the Swiss Jura Mountains. These model ecosystems excluded heterogeneity in soil and topography (shallow soil on limestone ridges, slope-aspect effects on microclimate). We focused on the process-pattern relationships during the self-organization processes among trait-conditioned vegetation dynamics and herbivore behavior. We improved the WoodPaM model by the re-calibration of tree species dispersal traits. The landscape patterns of baselinesimulations were checked for plausibility against aerial photographs. In experimental simulations, we artificially varied the parameterization of seed dispersal, resistance to browsing and shade tolerance of spruce and beech, as well as the rules for habitat preferences of livestock. From the corresponding landscape structural shifts, we analyzed the significance of traits and feedbacks in herbivore-vegetation 
interactions for landscape pattern formation. We follow previous approaches to pattern formation in alpine tree line ecotones (e.g. Malanson 1997). However, regarding the level of detail (tree species traits) and the consideration of processes at multiple scales, we go beyond previous studies. Our approach is rooted in the paradigm of "pattern-oriented modeling" (Wiegand et al. 1999; Grimm et al. 2005). We use a process-based model to elucidate cause-effect relationships that likely underlie complex patterns in space and time. Our bottom-up dynamic landscape modeling mechanistically relates a reasonable set of ecological processes and factors during (simulated) pattern formation. Within this framework, we demonstrate most likely cause-effect relationships based on a plausible (simulated) correspondence among factors (tree species traits and habitat use of livestock) and landscape patterns.

\section{Study areas}

Two pastures served as model systems: the sprucedominated Pré aux Veaux and the beech-dominated Métairie d'Evilard (Fig. 1). Both are similar in cattle grazing pressure, which is low (about 0.7 adult bovine units per ha for approximately 124 days per year; refer to Kohler et al. 2005; Peringer et al. 2013 for detailed information on land use). The elevation is also similar (1300 and $1250 \mathrm{~m}$ a.s.1.).

The dominance of spruce and near absence of beech in Pré aux Veaux is explained by the vast deforestations for charcoal burning in the Middle Ages around the Col des Amburnex (Sjogren 2006), from which beech could not recover under grazing pressure, and by the local climate. The pasture is located in a large, almost entirely closed valley with all year round frost events due to the accumulation of cold air. Beech buds and leaves are damaged by late frosts and beech individuals are only found on the valley shoulders. The dominance of beech in the Métairie d'Evilard is explained by its location at the top of a south-eastern slope (mild local climate, no accumulation of cold air) and by ancient management (firewood).

\section{The WoodPaM model}

WoodPaM is a grid-based model (square cell size is $25 \mathrm{~m}$ ) that operates at a yearly time step. At the cell level it simulates the dispersal, establishment and growth of tree species and shrubs and the succession of herb-layer communities. At the landscape level, it simulates the neighborhood dispersal and the longdistance dispersal of tree species, as well as the selective habitat use of livestock. Habitat selectivity considers herbaceous forage availability and tree cover. The baseline parameterization reflects habitat preferences of cattle, which focuses on productive grasslands and disregards dense tree canopies for foraging (Kohler et al. 2006). Thereby, a feedback is established in the model among the tree cover distribution at landscape-scale and the grazing and browsing impacts on woody plants and the herb-layer dynamics at the local-scale of grid cells. Based on this hierarchical and process-based structure (Fig. 3), WoodPaM is able to mimic multi-scale feedbacks in pattern formation, which emerge from herbivorevegetation interactions.

For our study, we re-calibrated the seed dispersal into neighboring cells and into all other cells (longdistance dispersal in a horizontal tail of the dispersal kernel) of spruce (Picea abies) and beech (Fagus sylvatica). Dispersal is fundamental for the recruitment of seedlings in the model, which is further constrained only by climate (drought, low winter temperatures) and safe sites provided by the herb layer communities (see Peringer et al. 2013 for details). The calibration of seed dispersal is documented in the Supplementary Material.

The survival of seedlings and saplings in the model is controlled by browsing pressure and their resistance to browsing, as well as by tree cover and their shade tolerance. The specific browsing resistance and shade tolerance of spruce and beech were parameterized based on established values from previous model applications (Gillet 2008; Peringer et al. 2013).

Browsing pressure is simulated as the damage by herbivores to seedlings and saplings that occurs synchronously to the grazing activity in a grid cell. The browsing pressure in relation to a given grazing pressure is defined by a functional relationship based on field investigations (Vandenberghe et al. 2007 among others) and reflects the selective foraging behavior of cattle. The grazing pressure is a function of habitat use. Grid cells with high amounts of herbaceous forage and low tree cover are intensively grazed. Herbaceous forage production depends on herb-layer communities, which range from (productive) pasture communities to (poor) understory. 
Fig. 3 Structure and main process interactions in the WoodPaM model. The processes that have been improved and experimentally varied are seed dispersal, browsing impact and shade tolerance of saplings

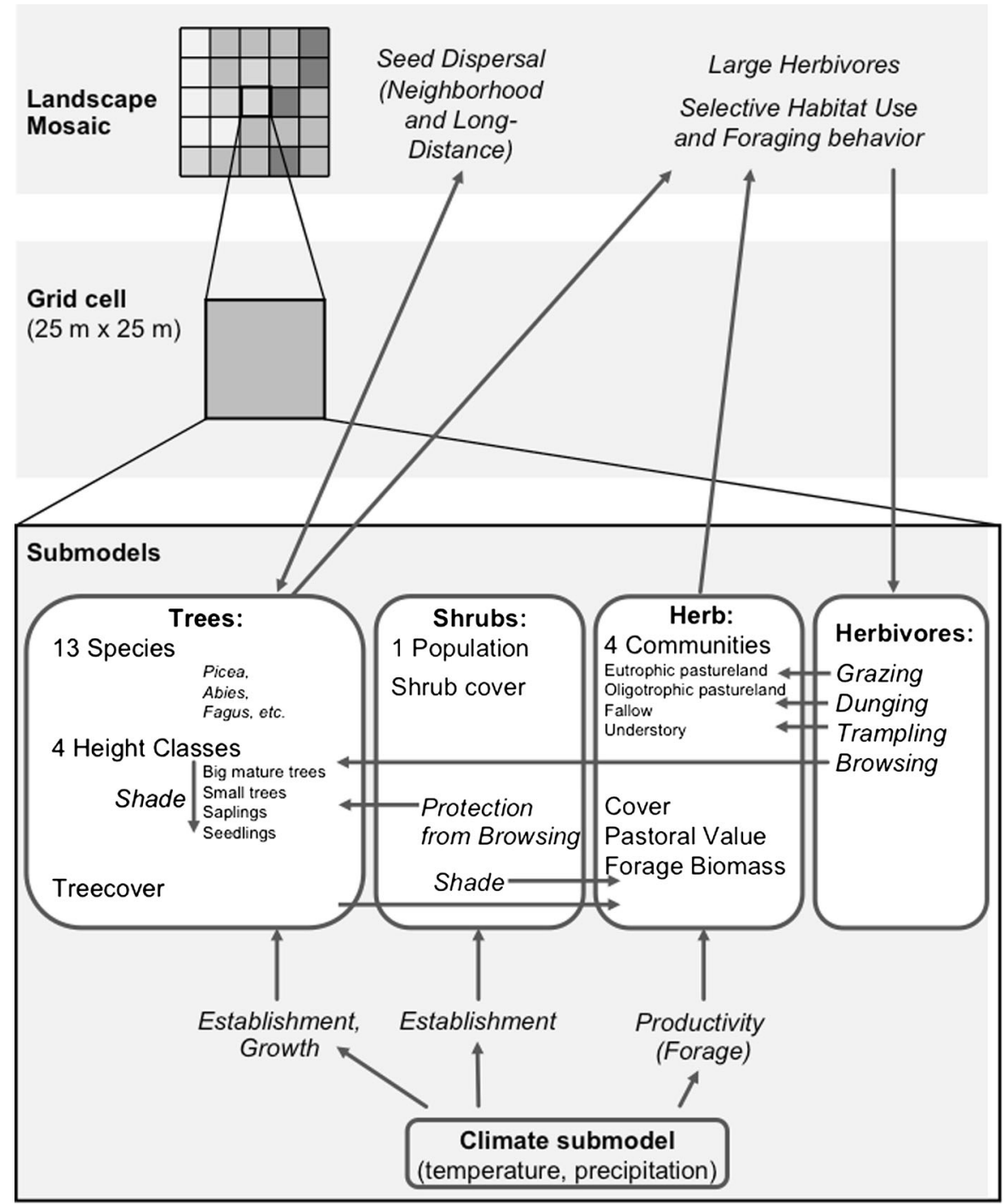

Successional transitions are mainly driven by tree cover (for details refer to Gillet 2008). In sum, in simulations with cattle grazing, browsing pressure was high on treeless grasslands and low in shrubland and forest.

Browsing resistance determines the mortality of seedlings and saplings for a given browsing pressure. In turn, seedlings and saplings of species with poor browsing resistance (such as beech) can only survive at low browsing pressure that occurs on sites that are disregarded by livestock for the reason of poor forage under dense forest canopies. To the contrary, browsing resistant species (such as spruce) can colonize even intensively grazed pastures where seed input is high.
Shade tolerance controls the simulated mortality of seedlings, saplings and young trees as a function of competition for light with taller trees. Only shadetolerant species can form dense forest canopies in the model, whereas canopies of poorly shade-tolerant species remain thin as a consequence of high mortality.

Simulated landscapes

WoodPaM simulations were performed for flat homogeneous landscapes, without geomorphological or soil heterogeneity, at two altitudes: $1330 \mathrm{~m}$ a.s.l., representing Pré aux Veaux with spruce-dominance, and 
$1250 \mathrm{~m}$ a.s.l., representing Métairie d'Evilard with beech-dominance. Baseline simulations aimed to reproduce the structural characteristics of these two landscapes and considered improved dispersal parameterization. To clearly separate spruce and beech for the analysis of species performance, we excluded beech from simulations of Pré aux Veaux and spruce from simulations of Métairie d'Evilard.

We initialized the model with only tree seedlings in simulation year 1 and ran a spin-up simulation for 500 years to allow the development of a closed mountain forest with site-specific species composition (either spruce or beech dominance). Afterwards, pasturing took place for 1500 years to simulate a potential equilibrium in the landscape, in which the mosaic landscape is shaped by herbivore-vegetation interactions (self-organization of landscape patterns). Due to the slow tree growth in mountain climate, shorter spin-up periods led to non-equilibrium states, which did not allow a stringent comparative analysis.

Simulations ran through cycles of a 100 year time series (1901-2000) of monthly temperature and precipitation (refer to Peringer et al. 2013 for details). Temperature and precipitation regimes were adapted to the specific altitudes of the study sites based on month-specific elevation lapse rates for temperature and precipitation (see Supplementary Material for details).

For land use, we set cattle grazing pressure to arbitrary but realistic values of low intensity to achieve approximately $40 \%$ tree cover in the baseline simulations. Thereby, the potential formation of all phytocoenosis types, grasslands and closed forest, was ensured. Low tree cover naturally limits the formation of dense forest stands and biases the comparison of landscape structural properties. We set 0.35 adult bovine units per ha for 124 days grazing duration per year in the beech-dominated pasture-woodland, and 0.45 for the spruce-dominated pasture-woodland. For the simulation of reduced browsing resistance of spruce we lowered grazing pressure to 0.15 adult bovine units per ha for 124 days, because in the case of 0.45 , tree cover was too low for a consistent structural analysis. For the simulation of increased resistance to browsing of beech, we increased grazing pressure to 0.7 because for 0.35 the tree cover was too high for a consistent structural analysis. In order to trigger pattern formation in an otherwise spatially homogeneous environment, we stochastically created gaps in the tree layer with a low frequency. Gap size and return interval were parameterized based on literature values for mountain forests in order to represent the mortality of senile trees (Zeibig et al. 2005; Schliemann and Bockheim 2011, see Supplementary Material). No further disturbance was considered (e.g. wild ungulates, windstorms, logging or shrub clearing).

Simulation experiments: regeneration traits and cattle habitat use

We experimentally created "artificial tree species" by stepwise shifting the three regeneration traits between spruce and beech; dispersal distances, browsing resistance and shade tolerance of beech saplings were assigned to spruce saplings and vice versa.

We experimentally created "artificial cattle" by the exclusion of its preference for treeless grassland in a simulation of the beech-dominated pasture-woodland. This "non-selective habitat use experiment" explores the role of the feedback among herbivores' habitat preferences and landscape structure (tree cover distribution) during forest-grassland segregation. The diet composition of cattle (partitioning of herbaceous forage and woody browse, i.e. simulated browsing pressure in relation to grazing activity) remained unchanged.

\section{Landscape analysis}

The structure of observed landscapes (Fig. 1) was analyzed based on aerial photograph interpretations regarding tree cover that were available from previous work (for the Pré aux Veaux refer to Chételat et al. 2013; for the Métairie d'Evilard refer to Kohler et al. 2005 and Gillet 2008). Tree cover classes followed the structure of phytocoenosis types (Gallandat et al. 1995, see Table 1). The area of phytocoenosis types was computed as percentage cover. We computed a series of landscape metrics in aggregated form for the whole landscape in FRAGSTATS (McGarigal et al. 2002). A selection of metrics was made that best distinguished the observed structural properties of the beech and the spruce-dominated pasture-woodlands. We selected (i) Patch Density (PD, the number of patches within the landscape) to quantify overall landscape heterogeneity, (ii) Edge Density (ED, the length of all borders between different patch types in the landscape divided by the total landscape area) to detect structural complexity of the forest-grassland mosaics, (iii) Total Core Area (TCA) of patches (with 
Fig. 4 Envelope patterns for simulated landscapes presented in Figs. 5 and 6. The cover of phytocoenosis types (black), the Landscape Aggregation Index AI (grey, both left $y$-axis) and the Total Core Area TCA (grey, dashed, right y-axis) are plotted along the gradient from grassland to forest (sequence of phytocoenosis types $1-4, x$-axis). The diagrams for spruce- and beech-dominated landscapes with modified browsing resistance, but baseline grazing pressure (refer to Figs. 3 and 4) are not shown. Due to shifts in overall tree cover, these scenarios are not adequate for structural comparison. For the definition of phytocoenosis types refer to Table 1 , for the definition of landscape metrics refer to "Landscape analysis"

\begin{tabular}{|c|c|c|}
\hline Scenario & $\begin{array}{l}\text { Spruce-dominated } \\
\text { pasture-woodland }\end{array}$ & $\begin{array}{l}\text { Beech-dominated } \\
\text { pasture-woodland }\end{array}$ \\
\hline Baseline & 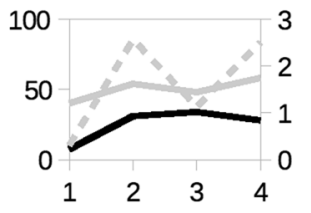 & $\underbrace{2}_{1}$ \\
\hline Dispersal & 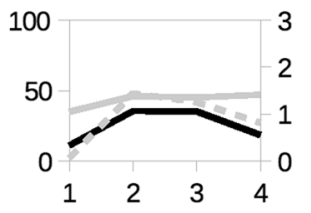 & 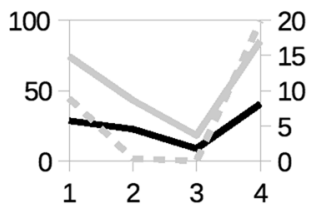 \\
\hline $\begin{array}{l}\text { Resistance to } \\
\text { browsing, adapted } \\
\text { grazing pressure }\end{array}$ & 10 & $100+20$ \\
\hline Shade tolerance & 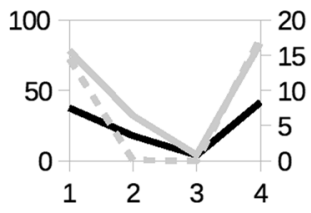 & $\underbrace{}_{3} \begin{array}{l}20 \\
-15 \\
-10 \\
5 \\
0\end{array}$ \\
\hline $\begin{array}{l}\text { Non-selective } \\
\text { habitat use }\end{array}$ & - & 100 \\
\hline
\end{tabular}

\section{Results}

a search distance of $25 \mathrm{~m}$ ) to demonstrate the landscape simplification into large patches, (iv) Contagion Index (CONTAG) to assess interspersion, i.e. the intermixing of units of different patch types, and (v) Aggregation Index (AI, $\mathrm{He}$ et al. 2000) to distinguish between coarse- and fine-grained landscape patterns. The TCA and the AI were also computed at the level of phytocoenosis types.

The structure of simulated landscapes was analyzed in the final simulation year 2000. As WoodPaM simulates tree cover, these maps were classified into phytocoenosis types (Table 1) and analyzed with the set of landscape metrics that indicate the "landscape structural envelope". We computed the area distribution, the TCA and the AI of phytocoenosis types. Furthermore, the maps of cattle habitat use were computed for each simulation to demonstrate the relationship between landscape structure and the allocation of grazing and browsing pressure.
Baseline simulations and model plausibility check

The simulated landscapes generally showed a higher tree cover than observed landscapes (compare the diagram in Fig. 2 to baseline simulations in Fig. 4). Treeless grasslands were underrepresented in the baseline simulation of the spruce-dominated landscape, whereas closed forest was overestimated. In the baseline simulation of the beech-dominated landscape, densely wooded pastures were underestimated to the favor of closed forest. Both are a consequence of the low grazing pressure in the simulations, which was assumed to achieve the formation of the full range of phytocoenosis types and comparable tree cover in the spruce- and the beech-dominated landscapes. Furthermore, any direct human interference was disregarded in the simulations: traditional pasture management in real 
landscapes (tree and shrub cutting) even at low intensity cleared sparsely wooded pastures to treeless grasslands and thinned out forest to densely wooded pastures. In sum, our simulation results showed an overall shift in the distribution of phytocoenosis types towards more woodland. Nevertheless, the baseline simulation of the beech-dominated landscape reproduced the characteristic "landscape structural envelope" as an indicator for forest-grassland segregation: forest-grassland ecotones were underrepresented and formed narrow fringes around forest (compare Figs. 2 and 4 under the consideration that phytocoenosis type 3 in observed landscapes corresponds to type 4 in simulated landscapes). The envelope failed to appear in the sprucedominated landscape (Fig. 4). Consistent with the observed landscape, the baseline simulation was characterized by large areas of gradual transition from forest to grassland and a balanced provision of phytocoenosis types (compare Figs. 2 and 4 under the consideration of higher tree cover in the simulated landscape). The habitat use of cattle was well distinguished according to the tree cover distributions; thin canopy spruce stands were readily grazed (Fig. 5). To the contrary, dense beech forests were poorly grazed and cattle focused on treeless grasslands (Fig. 6).

\section{Regeneration traits and cattle habitat use}

Reduced dispersal distances of spruce led to the emergence of slightly more treeless grasslands. Forest patches partly transformed into densely and sparsely wooded pastures as a consequence of generally reduced tree cover from weaker recruitment. Therefore, forestgrassland ecotones slightly increased in cover, but became smaller in patch size and slightly more disaggregated. The overall landscape structure and cattle habitat use remained similar (Figs. 4 and 5). Reduced resistance to browsing under baseline grazing pressure led to vanishing tree cover. For reduced grazing pressure, forest-grassland ecotones became even more dominant, expanded in size and aggregation (Fig. 4) and were readily grazed (Fig. 5). The increase of shade tolerance of spruce shifted the landscape structure towards forest-grassland segregation with dominating grassland and forest. Interconnecting ecotones were few ( $21.3 \%$ of sparsely and densely wooded pastures), highly disaggregated and small in patch size (Fig. 4), which corresponds to the "envelope" pattern in the observed beech-dominated landscape (Fig. 2). The dense forests became disregarded by cattle that focused on treeless grasslands (Fig. 5).

Increased dispersal distances of beech triggered the colonization of grasslands, and forest-grassland ecotones slightly enlarged and became more aggregated. However, the overall landscape structure and patterns of cattle habitat use remained unchanged (Figs. 4 and 6). Increased resistance to browsing under baseline grazing pressure led to large forest encroachment. For enhanced grazing pressure, there was almost no difference in landscape structure and cattle habitat use when compared to the baseline simulation (Figs. 4 and 6). The decrease of shade tolerance of beech shifted the landscape towards a dominance of forestgrassland ecotones (sparsely wooded pastures) with large patch size (TCA) and aggregated shape (AI). Densely wooded pastures were scattered (small TCA and AI, Fig. 4). Cattle habitat use was almost homogeneous (Fig. 6). The "envelope" characteristic of beech-dominated pasture-woodlands was inverted (Fig. 4). The same shift in landscape structure occurred for non-selective habitat use of cattle (Figs. 4 and 6).

\section{Discussion}

Role of dispersal and resistance to browsing in pattern formation

Until now dispersal, resistance to browsing and nursery plants have been the main focus for explaining the formation of forest-grassland mosaics in extensive grazing systems (Olff et al. 1999; Vandenberghe et al. 2007; van Uytvanck et al. 2008; Peringer and Rosenthal 2011). Our simulation experiments identified local- and landscape-scale characteristics of pasture-woodlands that depend on these tree species regeneration traits.

Dispersal distances are known to influence the width of forest-grassland ecotones (Peringer 2008; Peringer and Rosenthal 2011). We complement this understanding with a landscape perspective that demonstrates widespread dispersal leads to aggregation of forest-grassland ecotones towards large areas, whereas limited dispersal leads to disaggregation into small fringes. Nevertheless, we found dispersal distances to only play a local role in pattern formation. An influence on broad-scale landscape patterns (forest-grassland segregation) was not found.

We confirm browsing resistance to be a key trait in grassland-to-forest successions in pasture-woodlands 
Fig. 5 Simulated sprucedominated pasturewoodland mosaics, tree species distribution and corresponding grazing pressure (expressed as global utilization rate $\mathrm{GU}$, meaning percentage of consumed forage at pasture level). For the definition of phytocoenosis types see Table 1

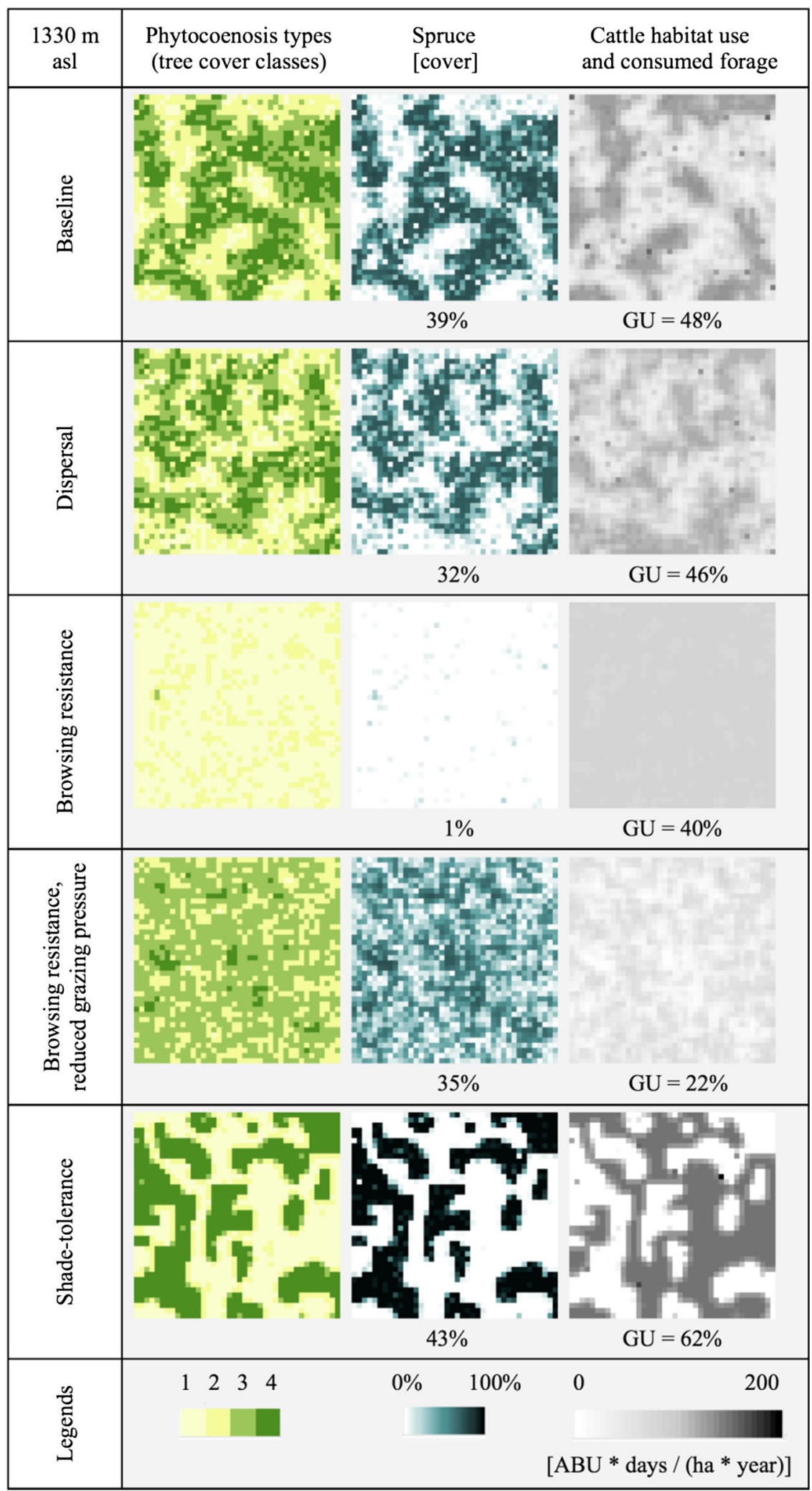


Fig. 6 Simulated beechdominated pasturewoodland mosaics, tree species distribution and corresponding grazing pressure (expressed as percentage of consumed forage). For the definition of phytocoenosis types see Table 1

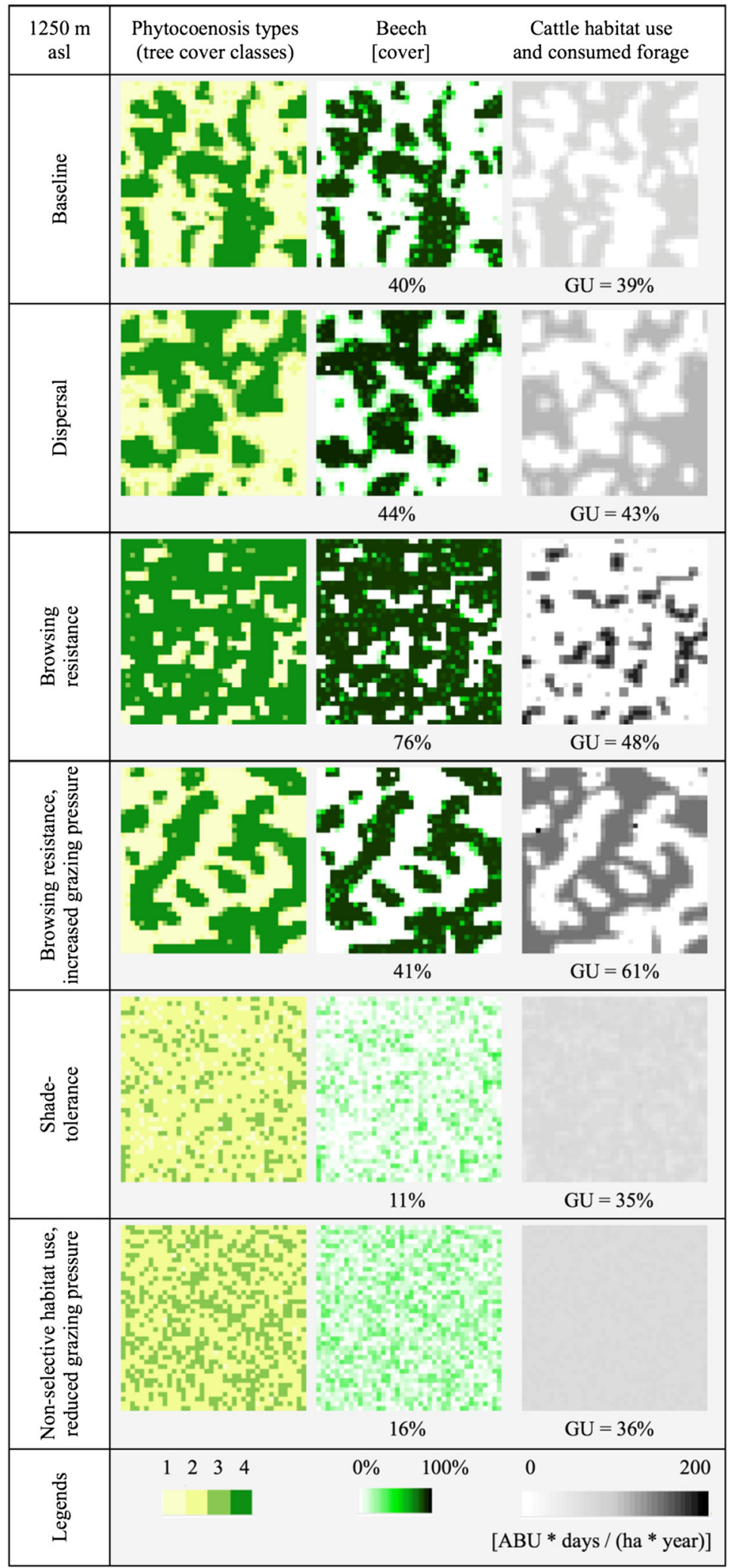


(Olff et al. 1999; van Uytvanck et al. 2008) as it determined overall tree cover by facilitating or inhibiting tree establishment under herbivore pressure in our simulations. However, the experimental modification of browsing resistance did not trigger substantial shifts in key landscape structural characteristics ("envelope" of forest-grassland segregation). Consequently, our study did not suggest significance of browsing resistance for the forest-grassland mosaic pattern.

Shade tolerance of tree saplings triggers landscape-scale feedbacks in herbivore-vegetation interactions

Our simulations for the first time propose shade tolerance of saplings to be a highly significant tree species regeneration trait in pasture-woodland mosaic pattern formation. Unlike dispersal and browsing resistance, we found modifications of shade tolerance of tree saplings to trigger shifts in landscape structure from originally contiguous towards segregated patterns and vice versa. We will argue that these shifts cannot be explained exclusively by local-scale consequences of different shade tolerance levels, i.e. the formation of dense or thin forest canopies. Instead, a multi-scale feedback among forest stand formation and the selective habitat use of herbivores appears to govern the emergence of contiguous or segregated forest-grassland mosaics. We discuss the potential mechanisms that underlie this feedback and thereby complement existing local-scale theory on mosaic pattern formation in pasture-woodlands.

The local-scale consequence of high shade tolerance of tree saplings is dense forest canopies. Our simulations showed a further unexpected effect: forest-grassland ecotones shrunk when the shade tolerance of spruce was artificially increased, the "envelope characteristic" of forest-grassland segregation emerged in the previously contiguous landscape. This outcome was counterintuitive because the high colonization ability of spruce remained unchanged (long dispersal distance and high browsing resistance) and is known to evoke large forest-grassland ecotones. Vice versa, when the shade tolerance of beech was artificially decreased, the "envelope characteristic" was inverted. Counterintuitively again, large and aggregated areas of forestgrassland ecotones were evoked, although the colonization ability (of beech) remained limited. Thereby, a complex mechanism in mosaic pattern formation is indicated, in which shade tolerance and tree canopy density govern a landscape structural property (presence and spatial distribution of forest-grassland ecotones), on which they do not have a direct influence. Moreover, this property was previously thought to depend on other tree species traits (dispersal distance and browsing resistance, refer to the first section of the discussion). Our simulation of non-selective habitat use of cattle proposes habitat preferences of herbivores to be a second factor in the formation of contiguous versus segregated mosaic patterns: the "envelope characteristic" of the beech-dominated pasture-woodland disappeared when tree cover was excluded from the habitat preferences of cattle, although the regeneration traits of beech remain unchanged (high shade tolerance). In sum, two processes at distinct scales contributed to forest-grassland segregation: local-scale formation of dense tree canopies and landscape-scale habitat selection of large herbivores. The analysis of simulated cause-effect relationships plausibly explains the multiscale feedback among the two processes, the way it triggers forest-grassland segregation and how it overrides local-scale vegetation dynamics driven by dispersal and browsing resistance. In the case of non-selective habitat use in the beech-dominated landscape, forest grazing hindered forest canopy closure and overall grazing pressure was reduced as the herb layer under thin canopies provided forage. In turn, beech could establish on grasslands regardless of poor colonization ability, as survival rates were high for the few seedlings from long-distance dispersal ("grazing refuges" sensu Smit et al. 2015). Subsequently, large forest-grassland ecotones emerged. The distribution of woods was disperse, as they emerged from long-distance dispersal with a (simulated) flat tail of the dispersal kernel, and reflected the characteristics of isolated single-tree patterns. These are known to emerge from shiftingmosaic cycles following scattered distributions of nurse shrubs and long-distance zoochory of browsing sensitive trees (Olff et al. 1999). To the contrary, in the case of selective habitat use (in the way of "grazers" sensu Hofmann and Scheibe 1997), emerging woods are avoided and, given the high shade tolerance of tree saplings, dense canopies developed. The forage in the herb layer became poor and in turn grazing pressure increased in the open land. Here, tree establishment became suppressed and a segregated landscape consisting of treeless grasslands and dense forests resulted. 
The degree of segregation of forests and grasslands, when progressive succession (tree encroachment and subsequent canopy densification) and regressive succession (increasing suppression of further tree establishment on grasslands due to forage limitation) have reached a natural balance, is determined by the relative importance and strength of the two interacting processes. Denser forest canopies in the mountains (with climate warming) and stronger preference for treeless grasslands (with high quality forage for productive livestock breeds) will promote segregation, whereas thin canopies (in harsh mountain climate or from traditional single-tree logging) and more "intermediate" foraging herbivores (sensu Hofmann and Scheibe 1997) such as wild ungulates in wilderness areas (e.g. wisent Bison bonasus and red deer Cervus elaphus) will hinder segregation.

In conclusion, the formation of segregated or contiguous forest-grassland mosaics is neither explained by vegetation properties, such as tree species traits that condition local vegetation dynamics, nor by landscape-scale habitat preferences of herbivores alone, but requires the consideration of the complex feedback among these factors across spatial hierarchies (Senft et al. 1987). Their interaction is characteristic for largescale grazing systems or wilderness areas, where herds of herbivores can freely roam (selectivity at macro-level sensu Wallis De Vries and Schippers 1994) and vegetation can form dynamic patch mosaics (Watt 1947). However, the management experience (land-use traditions) from pasture-woodlands with cattle grazing can be transferred to wilderness areas with wild ungulates only in a limited way, as a fundamental factor in landscape pattern formation is different, i.e. the habitat preferences of large herbivores.

Acknowledgments This work was supported by the CCES (Competence Centre Environment and Sustainability of the ETH Domain, Switzerland) as part of the MOUNTLAND project and by the Swiss Enlargement Contribution in the framework of the Romanian-Swiss Research Program as part of the WindLandproject (project code: IZERZO 142168/1 and 22 RO-CH/RSRP).

\section{References}

Ammer C (1998) Die Fichte in der natürlichen Verjüngung des Bergmischwalds. Allg Forst Z 53:396-399

Bergmeier E, Petermann J, Schröder E (2010) Geobotanical survey of wood-pasture habitats in Europe: diversity, threats and conservation. Biodivers Conserv 19(11):2995-3014
Chételat J, Kalbermatten M, Lannas KSM, Spiegelberger T, Wettstein J, Gillet F, Peringer A, Buttler A (2013) A contextual analysis of land-use and vegetation changes in two wooded pastures in the Swiss Jura Mountains. Ecol Socy 18(1):39

Donlan CJ, Berger J, Bock CE, Bock JH, Burney DA, Estes JA, Foreman D, Martin PS, Roemer GW, Smith FA, Soulé ME, Greene HW (2006) Pleistocene rewilding: an optimistic agenda for twenty-first century conservation. Am Nat 168(5):660-681

Dovčiak M, Hrivnák R, Ujházy K, Gömöry D (2008) Seed rain and environmental controls on invasion of Picea abies into grassland. Plant Ecol 194(1):135-148

Etienne M (ed) (1996) Western European silvopastoral systems. INRA Editions, Paris

Gallandat J, Gillet F, Havlicek E, Perrenoud A (1995) Typologie et systémique phyto-écologiques des pâturages boisés du Jura suisse. Laboratoire d'écologie végétale, Université de Neuchâtel, rapport final de mandat Offices fédéraux et cantonaux

Gillet F (2008) Modelling vegetation dynamics in heterogeneous pasture-woodland landscapes. Ecol Model 217(1-2):1-18

Gillet F, Gallandat J (1996) Wooded pastures of the Jura mountains. In: Etienne $M$ (ed) Western European silvopastoral systems. INRA Editions, Paris, pp 37-53

Grimm V, Revilla E, Berger U, Jeltsch F, Mooij WM, Railsback SF, Thulke HH, Weiner J, Wiegand T, DeAngelis DL (2005) Pattern-oriented modeling of agent-based complex systems: lessons from ecology. Science 310(5750):987

Hartel T, Plieninger T (eds) (2014) European wood-pastures in transition: A social-ecological approach. Routledge Chapman \& Hall

Hartel T, Dorresteijn I, Klein C, Máthé O, Moga CI, Öllerer K, Roellig M, Wehrden H von, Fischer J (2013) Wood-pastures in a traditional rural region of Eastern Europe: characteristics, management and status. Biol Conserv 166:267-275

He HS, DeZonia BE, Mladenoff DJ (2000) An aggregation index (AI) to quantify spatial patterns of landscapes. Landscape Ecol 15:591-601

Hofmann R, Scheibe K (1997) Ursprüngliche großsäugerartengemeinschaft als teil der naturlandschaft. Brandenburg Umw Ber 1:112-117

Hopkins JJ, Kirby KJ (2007) Ecological change in British broadleaved woodland since 1947. Ibis 149:29-40

Iverson L, McKenzie D (2013) Tree-species range shifts in a changing climate: detecting, modeling, assisting. Landscape Ecol 28(5):879-889

Jensen TS (1985) Seed-seed predator interactions of european beech, fagus silvatica and forest rodents, clethrionomys glareolus and apodemus flavicollis. Oikos 44(1):149

Johnson WC, Adkisson CS (1985) Dispersal of beech nuts by blue jays in fragmented landscapes. Am Midl Nat 113(2):319-324

Jørgensen D (2013) Pigs and pollards: medieval insights for UK wood pasture restoration. Sustainability 5(2):387-399

Kohler F, Hamelin J, Gillet F, Gobat J, Buttler A (2005) Soil microbial community changes in wooded mountain pastures due to simulated effects of cattle grazing. Plant Soil 278(1-2):327-340

Kohler F, Gillet F, Reust S, Wagner HH, Gadallah F, Gobat J, Buttler A (2006) Spatial and seasonal patterns of cattle 
habitat use in a mountain wooded pasture. Landscape Ecol 21(2):281-295

Kunstler G, Curt T, Lepart J (2004) Spatial pattern of beech (Fagus sylvatica L.) and oak (Quercus pubescens Mill.) seedlings in natural pine (Pinus sylvestris L.) woodlands. Eur J Forest Res 123(4):331-337

Lederbogen D, Rosenthal G, Scholle D, Trautner J, Zimmermann B, Kaule G (2004) Allmendweiden in Südbayern: Naturschutz durch landwirtschaftliche Nutzung. Bundesamt für Naturschutz (Hrsg.), Reihe für Angewandte Landschaftsökologie (62)

Malanson G (1997) Effects of feedbacks and seed rain on ecotone patterns. Landscape Ecol 12(1):27-38

Martínez I, González-Taboada F (2009) Seed dispersal patterns in a temperate forest during a mast event: performance of alternative dispersal kernels. Oecologia 159(2):389-400

McGarigal K, Cushman SA, Neel MC, Ene E (2002) FRAGSTATS: Spatial Pattern Analysis Program for Categorical Maps. Computer software program produced by the authors at the University of Massachusetts, Amherst http:// www.umass.edu/landeco/research/fragstats/fragstats.html

Navarro L, Pereira H (2012) Rewilding abandoned landscapes in Europe. Ecosystems 15(6):900-912

Olff H, Vera FWM, Bokdam J, Bakker ES, Gleichman JM, Maeyer K de, Smit R (1999) Shifting mosaics in grazed woodlands driven by the alternation of plant facilitation and competition. Plant Biol 1(2):127-137

Peringer A (2008) Analyse von Mechanismen der sekundären progressiven Sukzession von voralpinem Niedermoorgrünland zu Erlenbruchwald. Dissertation, Stuttgart

Peringer A, Rosenthal G (2011) Establishment patterns in a secondary tree line ecotone. Ecol Model 222(17):3120-3131

Peringer A, Siehoff S, Chételat J, Spiegelberger T, Buttler A, Gillet F (2013) Past and future landscape dynamics in pasture-woodlands of the Swiss Jura Mountains under climate change. Ecol Soc 18(3):11

Perrenoud A, Känzig-Schoch U, Schneider O, Wettstein J (2003) Exploitation durable des pâturages boisés: un exemple appliqué du Jura suisse-Nachhaltige Bewirtschaftung von Wytweiden: ein Beispiel aus dem Schweizer Jura. Haupt, Bern

Redecker B, Härdtle W, Finck P, Riecken U, Schröder E (eds) (2002) Pasture landscapes and nature conservation. Springer, Berlin

Rosenthal G (2010) Wiederbewaldung von beweideten mooren des alpenvorlandes. Tuexenia 30:83-104

Rosenthal G, Schrautzer J, Eichberg C (2012) Low-intensity grazing with domestic herbivores: a tool for maintaining and restoring plant diversity in temperate Europe. Tuexenia 32:167-205

Rustad L, Campbell J, Marion G, Norby R, Mitchell M, Hartley A, Cornelissen J, Gurevitch J, GCTE-NEWS (2001) A meta-analysis of the response of soil respiration, net nitrogen mineralization, and aboveground plant growth to experimental ecosystem warming. Oecologia 126(4):543562

Schliemann SA, Bockheim JG (2011) Methods for studying treefall gaps: a review. For Ecol Manag 261(7):1143-1151

Senft RL, Coughenour MB, Bailey DW, Rittenhouse LR, Sala OE, Swift DM (1987) Large herbivore foraging and ecological hierarchies. Bioscience 37(11):789-799

Sjogren PJE (2006) The development of pasture woodland in the southwest Swiss Jura Mountains over 2000 years, based on three adjacent peat profiles. Holocene 16(2):210-223

Smit C, Vandenberghe C, den Ouden J, Müller-Schärer H (2007) Nurse plants, tree saplings and grazing pressure: changes in facilitation along a biotic environmental gradient. Oecologia 152(2):265-273

Smit C, Ruifrok JL, van Klink R, Olff H (2015) Rewilding with large herbivores: the importance of grazing refuges for sapling establishment and wood-pasture formation. Biol Conserv 182:134-142

van Uytvanck J, Decleer K, Hoffmann M (2008) Establishment patterns of woody species in low intensity-grazed pastures after the cessation of intensive agricultural use. For Ecol Manage 256(1-2):106-113

Vandenberghe C (2006) The influence of cattle activity on tree regeneration in wood-pastures. Doctoral dissertation, Lausanne

Vandenberghe C, Freléchoux F, Moravie MA, Gadallah F, Buttler A (2007) Short-term effects of cattle browsing on tree sapling growth in mountain wooded pastures. Plant Ecol 188(2):253-264

Vandenberghe C, Freléchoux F, Buttler A (2008) The influence of competition from herbaceous vegetation and shade on simulated browsing tolerance of coniferous and deciduous saplings. Oikos 117(3):415-423

Wallis De Vries MF, Schippers P (1994) Foraging in a landscape mosaic: selection for energy and minerals in free-ranging cattle. Oecologia 100(1-2):107-117

Wallis De Vries MF, Bakker JP, van Wieren SE (1998) Grazing and conservation management. Kluwer Academic Publishers, Berlin

Watt AS (1947) Pattern and process in the plant community. J Ecol 35(1/2):1-22

Wiegand T, Moloney KA, Naves J, Knauer F (1999) Finding the missing link between landscape structure and population dynamics: a spatially explicit perspective. Am Nat 154(6):605-627

Zeibig A, Diaci J, Wagner S (2005) Gap disturbance patterns of a Fagus sylvatica virgin forest remnant in the mountain vegetation belt of Slovenia. For Snow Landscape Res 79(1-2):69-80 